NBER WORKING PAPER SERIES

\title{
PRICES AND TERMS OF TRADE FOR DEVELOPED-COUNTRY EXPORTS OF MANUFACTURED GOODS
}

\author{
Irving B. Kravis \\ Robert E. Lipsey
}

Working Paper No. $\underline{77}$

\author{
NATIONAL BUREAU OF ECONOMIC RESEARCH \\ 1050 Massachusetts Avenue \\ Cambridge MA 02138 \\ September 1981
}

University of Pennsylvania and NBER, and Queens College, City University of New York and NBER, respectively. This paper was presented in preliminary form at the meeting of the International Econornic Association on Problems of Changes in Relative Prices in Athens, Greece, August 31-September 5, 1981. It was prepared mainly as part of the NBER's study of The Indexing of Commodity Prices, financed by Grant No. APR77-06822 from the National Science Foundation, and also draws on work under NSF Grant No. SES-7925724 on Export Growth, Export Prices, and the Supply of Exports. We are indebted to Linda O'Connor, with assistance from Kathy Lembo and Vanessa Kooby, for programming and data collection, to Robert J. Gordon for the use of unpublished price data, and to Muriel Moeller for the preparation of the manuscript. Several of the participants in the conference, particularly Graham Hall, T.S. Khachaturov, Alfred Maizels, Pedro Malan, Katma Prasad, Sir Austin Robinson and J.R. Wells, made useful comments and suggestions. The research reported here is part of the NBER's research program in International studies. Any opinions expressed are those of the authors and do not necessarily represent those of the National Bureau of Economic Research or the National Science Foundation. 


\section{Prices and Terms of Trade for Developed- Country Exports of Manufactured Goods}

\section{ABSTRACT}

The purpose of this paper is to contribute some new measurements to the discussion of trends in the terms of trade between manufactured goods exports of developed countries and primary product exports of developing countries. The new measures are nanufactured goods price indexes that are derived from price data rather than from unit value data and include some corrections for quality change.

Our calculations indicate that the prices of manufactured goods exported by developed countries to developing countries have risen over twenty years or so by 75 per cent, as compared to the 14 ? per cent shown iy the generally used UN unit value indexes. The decline in terms of trade for these goods relative to prinary products has been almost 50 per cent over this period.

Over the last hundred years, fluctuations in the terms of trade of manufactured goods relative to primary products have been very wide, as far as we can tell from the inadequate measures we have. Impressions about trends have been highly dependent on choices of beginning and end years. There is very little evidence for a long-run trend in either direction.

Irving B. Kravis Department of Economics University of Pennsylvania Philadelphia, Pennsylvania 19174

(215) 243-5692
Robert E. Lipsey

National Bureau of Economic Research 269 Mercer Street New York, New York 10003

(212) $598-3533$ 


\section{PRICLS AND TLLIS OF TRAUL TOR DUVLLOPLL- \\ COUNTRY LAPORTS OF YAIUFACTLRED GOOD: \\ Irvinis L. Lravis \\ Rovert L. Lipsey}

The subject of terms of trade between lanufacturec goods and primary products has a lon history, and opinions on the direction of trends in them have gone tinrough several cycles. Recently, until the last few years, the majority opinion, especially in ceveloping countries and in agencies representing tieir views, has been that manufactured goods have melerally risen in price over a century or so. This was true despite the fact that such a rise would have violently contradicted one of the most firmly held and basic beliefs of classical economics. That was that as a consequence of diminishing returns--of rising population pressing against a constant supply of resources, especially land--there must be in the long run a rise in primary goods prices, especially agricultural prices, relative to prices of manufactured goods. For example:

"The tendency, then, being to a perpetual increase in the productive power of labour in manufactures, while in agriculture and mining there is a conflict between two tendencies, the one towards an increase of productive power, the other towards a diminution of it, the cost of production being lessened by every improvement in the processes, and augmented by every addition to population; it follows that the exchange value of manufactured articles, compared with the products of agriculture and of mines, have, as population and industry advance, a certain and decided tendency to fall." (Mill, 1848, Book IV, Ch. II.) 
Tne classical view was the dominant one, particularly in Great iritain. It was empiasized in times of rising raw materials prices, as in Jevons (1866), Keynes (1912), and Robertson (1915), and subsided when prices declined, as in the late 19 th century and after World war 1.1

The opposite picture as to the facts of the case was drawn a century later by Folke Hilgerdt, in Industrialization and Foreign Trade, which concluded that in the 60 years before 1938, primary product prices had fallen relative to prices of manufactures and that "the general trend of the relative movements.... of the prices of these two classes of goods can scarcely be doubted."

What is particularly astonishing about this conclusion is that after over a century of confident theorizing that exactly the opposite trend was inevitable and a historical fact, Hilgerdt offered this conclusion without any reference to the contradiction of classical doctrine.

The theme of relatively declining primary goods prices was then taken up in a long series of documents, many published by the United Nations Economic Commission for Latin America and written by, or under the direction of Raul Prebisch, director of ECLA and later of UNCTAD. Among them were Relative Prices of Exnorts and Imnorts of Underdeveloped Countries (1949) and The Economic Development of Latin America and Its Principal Problems (1950) and an article by lians Singer on "The Distribution of Gains between Investing and Borrowing Countries," American Economic Review, lay 1950. This doctrine, and the explanations given for it, 1 For a review of the fluctuations of opinion see Rostow (1978). 
became known as the Singer-Prebisch thesis, despite its origins with Hilgerdt who really never developed the theme or gave it the importance that was later attributed to it.

A few dissenters, such as Haberler and Viner, were never convinced by Hilgerdt's data or the UN line in general, although they had no counter-evidence to offer. Several pointed to the likelihood that price indexes for manufactured goods, and therefore for exports of industrial countries, suffered from upward bias due to the neglect of quality change and the underrepresentation of new commodities. Export prices for automobiles, for example, might not take into account gains in horsepower, the shift to power brakes and steering, anti-pollution devices, etc. If this were the case, the improvement in terms of trade would be exaggerated since the export price indexes for LDC's, or for primary products, were not subject to the same biases.

The issue has continued to be argued back and forth in the journals and in several books, and with interest recently renewed in connection with proposals for commodity price indexation, and some progress has resulted from the reworking of the historical data. ${ }^{2}$ However, almost ai: these studies have relied on similar basic data: unit value indexes tor prices of manufactured and primary products exports. The defects of these data, especially with respect to manufactured goods, are vell known, $^{3}$ and most authors tip their hats to them and then proceed to use

2

A small selection would include Cuddy (1976), Ellsworth (1956), Kaberler (1961), Kindleberger (1956), Lipsey (1963), ilontgoriery (1960), íorgan (1963), Spraos (1980), lates (1959).

3 As pointed out in Kravis and Lipsey (1971) and (1974). 
the data anyway for lack of good alternatives. however, over the last few decades, some improved data for prices have become available.

Our purpose in this paper is to make a contribution to the progress of this discussion in several ways. First we discuss briefly some issues relating to methods of calculating price movements for groups of countries. Then we present some price indexes for manufactured products exported by developed countries for the period since 1953 that do not depend at all on the use of unit values from trade statistics. We examine the divergence of the more commoniy used unit value indexes from these price indexes, particularly with respect to the implications for recent trends in the terms of trade. We offer some assessment of the impact of quality changes on price measures for manufactures and relate tinese to terms of trade movements. Finally, for the sake of providing a rough perspective on long term changes we reluctantly resort to unit value indexes for the three quarters of a century prior to the early $1950^{\prime}$ s wien our own price series begin.

\section{Price Indexes for Developed Country Exports of Manufactures}

There are several basic ingredients for our indexes, which we sumarize were anciescribe nore fully ir tive appendix. The first are our own international price indexes for metals, netal products, machinery, anci transport equipment, for the United States, the United Kingdon, Germany, and Japan, covering 1953-1964. ${ }^{4}$ The second are the export price indexes developed over the last twenty years or more, mainly by

4 Kravis and Lipsey (1971). 
the U.S., Germany, and Japan, the latter two comprehensive, the first starting with the same coverage as our indexes and gradually increasing coverage over time. The third element of our indexes is more fragmentary export price data published by the U.K., Sweden, and the Netherlands, the last gradually increasing in scope over the years. The fourth type of data is producer price indexes and/or wholesale price indexes for all the countries included here. The fifth type is hedonic price indexes for a few types of machinery and transport equipment. These are used in two ways. The first is to fill in prices for some commodities for which no official published indexes exist. The second is as a substitute for conventional price series in a very rough attempt at adjustment for quality change where we consider it appropriate and important.

These various sources of data of course overlap extensively, and it is necessary for us to assign price series to the index by a system of priorities, determined by our views as to the appropriateness of each type of data as measures of export prices. The highest priority is given to our own series, with interpolations based on the other types of data as explained for the case of Germany in Kravis and Lipsey (1972). The second priority is to official export price series, the third to producer or wholesale prices, and the fourth to the hedonic price indexes. Although we consider the hedonic price series more appropriate for our purposes than the conventional series we have not given them priority because we wished to produce an index from something close to conventional data. However, we have also calculated an alternative index in which hedonic price series are given priority, and we consider that to be the best estimate we can make of the movement of prices of manufactured goods. 


\section{Designing a World or Regional Price Index}

Aside from the selection of basic price data, the most important choice is that of a weighting system, a topic on which we have experimented a little and plan to study further. The decision on a weighting system is apart from that on base years, for which we use 1963 here, although we intend to experiment also with a 1975 base.

The principal version of a manufactures price index used here, which we will refer to as Type A, weights the export price series by the 1963 values of exports by all developed countries to all developing countries. This is done for each country's prices at the four-digit SITC level, to produce country indexes with common weights, and then the country indexes are combined using the values of each country's exports of all manufactured products to LDC's to form a general DC export price index. One difficulty with this scheme is that it requires sufficient coverage of all manufactures to permit the calculation of an overall index. If a country's price data are too skimpy for that, they do not appear in the total index even though they may be sufficient for some groups and even though the country may be an important exporter in some groups.

A second manufactures price index, shown in the Appendix, which we refer to as Type $B$, welghts each export price series by the 1963 value of that country's exports of that product to developing countries. The country aggregate price index is, as in the Type A price index, weighted by each country's exports of all manufactures to developing countries.

Although these are the only indexes of manufactures export prices presented here, we plan to calculate several others. In general, they involve the use of each country's own weights to form the index numbers for segments of manufactures (e.g., one-digit or two-digit SITC categories) and the weighting across countries at levels below the total of all manufactures.

The maximum use of the available price data would be made by weighting each price observation by the value of exports of that commodity by that country to developing countries (Type E). 
If we think of the weights in the form of a country by commodity matrix,

\begin{tabular}{|c|c|c|c|c|}
\hline \multirow[b]{2}{*}{ Cormodity } & & & & \\
\hline & 1 & 2 & 3 & $\ldots \ldots \ldots m$ \\
\hline 1 & $\omega_{11}$ & $\omega_{12}$ & $w_{13}$ & $\cdots \cdots \omega_{1 m}$ \\
\hline 2 & $w_{21}$ & $w_{22}$ & $\omega_{23}$ & $\ldots \ldots \omega^{\omega} 2 \mathrm{~m}$ \\
\hline 3 & $w_{31}$ & $w_{32}$ & $w_{33}$ & $\ldots \ldots \omega_{3 m}$ \\
\hline • & $\cdot$ & . & • & $\ldots \ldots$ \\
\hline - & - & - & - & $\ldots \ldots$ \\
\hline $\mathrm{n}$ & $w_{n 1}$ & $w_{n 2}$ & $w_{n 3}$ & $\ldots \ldots \omega_{n m}$ \\
\hline
\end{tabular}

the Type A index presented here could be described as $A=\frac{\sum_{j=1}^{m} \omega_{j} \sum_{i=1}^{n} \omega_{i} p_{i j}}{\omega}$ and the other extreme, the Type $E$, as $E=\sum_{j=1}^{m} \sum_{i=1}^{n} \omega_{i j} P_{i j}$. In tile case of an index of Type A the weigint for a price is $\frac{\omega_{j} \omega_{i}}{\omega}$ while in the $E$ index weight is $\omega_{i j}$.

The importance of these choices arises from the fact that each involves not .......y weighting but also different assumptions about the nature of the commodities priced at the most detailed level and about price relationships. The reason is that each involves different ways of filling in missing price observations. The justification for starting with the calculation of country indexes is the assumption that missing prices tend to behave in a similar manner to the average of other prices in the same country for commodities in the same 3-digit, 2-digit, or 1-digit commodity classes. These methods 
therefore ignore the behavior of other countries' prices for the same commodity, a difficult assumption to accept for anyone who believes the law of one price has any validity at all. In contrast, tine methods that start with the calculation of indexes for all countries at the 4-digit SITC level come closer to acceptance of the law of one price, since they assume that one country's price for a commodity tends to move with the average of other countries' prices for the same commodity. However, they therefore assume that there is no country-specific effect on a price change. Thus a currency revaluation has no effect on the export price of the revaluing country in comparison to that of others, a proposition we have found to be frequently contradicted in our studies of international price behavior. 5

Since neither of these two extreme assumptions seems really acceptable we plan eventually to drop them both by using a method that incorporates both country and conmodity effects in estimating each missing price. The method is a variant of one developed by Summers (1973) for the estimation of inter-country price level comparisons. It involves fitting an equation to each block of country and commodity price observations, the block being defined by the full list of commodities and countries or by the countries and some level of commodities, such as all those in a two-digit SITC class. The equation contains dummy variables for both country and commodity and therefore permits the data to determine the degrees to which the two characteristics influence the estimated price.

\section{Price and Unit Value Indexes for Manufactures Exports}

A preliminary Type A index for manufactured product exports of developed countries to developing countries is shown in Table 1 . Only 
TABLE 1

NBER Price Index for Manufactures (SITC 5-8) and Comparison with UN Unit Value Indexes

(1963=100 and each year compared with previous one)

\begin{tabular}{|c|c|c|c|c|c|c|}
\hline & \multicolumn{3}{|c|}{$1963=100$} & \multicolumn{3}{|c|}{$\begin{array}{c}\text { Each Year Compared with } \\
\text { Previous Year } \\
\text { (Per cent change }\end{array}$} \\
\hline & \multirow[b]{2}{*}{$\begin{array}{l}\text { IJBER } \\
\text { Price } \\
\text { Index } \\
\quad(1)\end{array}$} & \multicolumn{2}{|c|}{ UN Unit Value Indexes } & \multirow[b]{2}{*}{$\begin{array}{l}\text { NBER } \\
\text { Price } \\
\text { Index } \\
\quad(4)\end{array}$} & \multicolumn{2}{|c|}{ UN Unit Value Indexes } \\
\hline & & $\begin{array}{l}\text { All } \\
\text { Manu- } \\
\text { factured } \\
\text { Exports } \\
\quad(2)\end{array}$ & $\begin{array}{l}\text { DC Exports } \\
\text { to LDC's } \\
\text { (3) }\end{array}$ & & $\begin{array}{c}\text { All } \\
\text { Manu- } \\
\text { factured } \\
\text { Exports } \\
(5)\end{array}$ & $\begin{array}{l}\text { DC Exports } \\
\text { to LDC's } \\
(6)\end{array}$ \\
\hline 1953 & 91.7 & 92 & 93.5 & & & \\
\hline 1954 & 91.0 & 91 & 90.9 & -0.8 & -1.1 & -2.8 \\
\hline 1955 & 92.5 & 91 & 91.6 & +1.6 & 0 & +0.7 \\
\hline 1956 & 96.3 & 95 & 93.7 & +4.1 & +4.4 & +2.3 \\
\hline 1957 & 99.4 & 98 & 97.5 & +3.2 & +3.2 & +4.1 \\
\hline 1958 & 99.1 & 97 & 98.3 & -0.3 & -1.0 & +0.8 \\
\hline 1959 & 99.5 & 96 & 97.2 & +0.4 & -1.0 & -1.1 \\
\hline 1960 & 99.9 & 98 & 99.5 & +0.4 & +2.1 & +2.4 \\
\hline 1961 & 100.5 & 99 & 99.7 & +0.6 & +1.0 & +0.2 \\
\hline 1962 & 100.0 & 99 & 99.3 & -0.5 & 0 & -0.4 \\
\hline 1963 & 100.0 & 100 & 100.0 & 0 & +1.0 & +0.7 \\
\hline 1964 & 101.5 & 101 & 102.0 & +1.5 & +1.0 & +2.0 \\
\hline 1965 & 103.0 & 103 & 104.9 & +1.5 & +2.0 & +2.8 \\
\hline 1966 & 104.8 & 106 & 105.6 & +1.7 & +2.9 & +0.7 \\
\hline 1967 & 105.6 & 107 & 107.0 & +0.8 & +0.9 & +1.3 \\
\hline 1968 & 104.7 & 107 & 99.8 & -0.9 & 0 & -6.7 \\
\hline 1969 & 107.6 & 110 & 100.8 & +2.8 & +2.8 & +1.0 \\
\hline$=970$ & 113.8 & 117 & 111.4 & +5.8 & +6.4 & +10.5 \\
\hline 1971 & 120.7 & 124 & 119.9 & +6.0 & +6.0 & +7.6 \\
\hline$I \bar{Y} 72$ & 129.4 & 134 & 132.1 & +7.2 & +8.1 & +10.2 \\
\hline 1973 & 145.1 & 156 & 157.9 & +12.2 & +16.4 & +19.5 \\
\hline 1974 & 171.4 & 190 & 195.5 & +18.1 & +21.8 & +23.8 \\
\hline 1975 & 189.2 & 213 & 225.3 & +10.4 & +12.3 & +15.2 \\
\hline 1976 & 193.3 & 215 & 227.1 & +2.2 & +0.5 & +0.7 \\
\hline 1977 & 208.6 & 233 & 245.2 & +7.9 & +8.7 & +8.0 \\
\hline
\end{tabular}


Notes to TABLE 1

\section{NBER Price Index}

This is a six-country composite, aggregation within countries by OECD export weights and between countries by value of exports of manufactures to developing countries.

The calculation of the index is described as Type A in the text. The six countries covered are the United States, the United Kingdom, Germany, Japan, Canada, and the Netherlands. The last two are missing from the indexes for the years before 1956, because data were completely lacking or too thin and the Netherlands indexes do not begin until 1962. The indexes for 1975-77 are based on less complete data than those for earlier years.

For sources of NBER price data, see Appendix.

UN Unit Value Index for All Manufactured Exports

Statistical Yearbook 1967 and Monthly Bulletin of Statistics, various issues.

UN Unit Value Index for Exports of Manufactures by Developed Countries to Developing Countries.

Monthly Bulletin of Statistics, Nov. 1965, Dec. 1971, June 1977, June 1980 . 
six exporting countries are included because they are the only ones for which we have sufficient coverage to produce indexes for total manufacturing. The aggregate index was quite stable over most of the period, with only two changes of more than 3 per cent before 1970 and an average change of only about one-half of one per cent per year between 1957 and 1967. In the 1970's, however, the increases became much larger, averaging almost 10 per cent per year. After rising only from 92 to 108 between 1953 and 1969, the index then jumped to over 200 by 1977 .

We also calculated a Type B price index for the same six countries. In this index the country indexes were aggregated with weights based on each country's exports to developing countries in 1963 rather than those of all countries combined, but the country indexes were combined in the same way as for the Type A index. To the extent that the 1963 weights reflected the previous ten years' price history, and elasticities of substitution were greater than one, we might expect that this index would have fallen relative to the Type A index, because a country would have a heavier weight (larger exports) for a product in which its prices had fallen relative to the other countries. However, the two indexes stayed very close together between 1953 and 1963 and changed by identical amounts over that period as a whole. After that the Type $B$ index tended to rise relative to the Type $A$ index, with the changes, never more than about a half a percentage point different in any one year, cumulating to an increase 5 per cent greater by 1977. In other words, higher than average country export weights in 1963 were correlated with larger than average price increases after that. 
We compare our Type A price index in Table 1 with two versions of the UN unit value index, the most frequently used currently avallable indicator of export price movements for manufactured goods. One of the UN series is the published export unit value index for total manufactured goods exports of developed market economies (Column 2). The second UN index (Column 3) is one we calculated from UN data for the unit values of exports by developed countries to developing countries for SITC 5, 7, and 6 plus 8 , which we combined using 1963 export weights. The second UN Index is a little closer in coverage to our own index, in the sense that ours is weighted by the values of exports by developed countries to developing countries although the prices we use are not specific to trade with developing countries. Despite these adjustments, it is virtually impossible to be sure what accounts for the differences between the UN indexes and ours. Not only are the UN indexes based on unit value data rather than price data, but the coverage of countries is somevhat wider, the index number formula is different, and the weighting is different. The wider coverage of the UN indexes is not a likely explanation for the divergences between our index and theirs because the additional countries are minor exporters of manufactured goods. The effects of the differences in weighting and index number formulas are more difficult to guess at without a close analysis, but the 
fact that ours is a Laspeyres index on a 1963 base is likely to make it rise more, rather than less, rapidly than the UN indexes in the later period of rising prices. 6

Whatever the reasons for the differences, we find that both UN indexes, after being quite close to the NBER series through the mid-1960's, rose considerably more during the following period of rapid price change. Furthermore the restriction of the UN series to exports to developing countries and the weighting at the 1-digit level by 1963 exports to match that of the NBER series (Col. 3) moved the UN series further away from, rather than closer to, the NBER index. For example, over the period from 1967 to 1977, at the beginning of which all three series were very close, the NBER series rose by 98 per cent, the total UN series by 118 per cent, and the UN series on exports to LDC's by 129 per cent. In the last five years the NBER index rose by 61 per cent, the full UN series by 74 per cent, and the UN index for exports to LDC's by 86 per cent. Thus we find indications that the unit value indexes exaggerate the increase in manufactured goods prices and that the exaggeration is largest during periods of rapid price change. We suspect, although we cannot prove it, that the differences are due to the use of unit values rather than to differences in index number formulas or weighting. 7

6

This is not necessarily the case, however. For some discussion and examples see Hansen and Lucas (1981) and Lipsey (1963).

7

An odd feature of the unit value series we constructed from UN series for exports by developed countries to developing countries is the sharp decline, by about 7 per cent, in 1968. The NBER index shows a slight decline that year and the overall UN index none at all. The most 
In an earlier study (Kravis and Lipsey, 1971) we compared our indexes for machinery and transport equipment from 1953 to 1964 with the corresponding export unit value indexes published by the United Nations. We concluded there that at least in these products, the unit value indexes were biased upwards to a substantial degree. That relationship persists in the indexes used here, but it is offset in the aggregate by a much larger decline In the unit value index than in the price index for chemicals, espectally between 1957 and 1961.

\section{The Treatment of Missing Prices}

Each type of index involves some assumptions about missing price change observations. The Type A index used here assumes that a missing price chanpe, in a country for which we have other price data, resembles the changes in nrices of other commodities in the same commodity group in that country. We make no use, in this index, of information about prices of the same commodity in other countries. For countries other than the six included in the Type A index, however, we are in effect assuming that their price movements resemble those of these six countries for which we do have fairly complete data.

Fn. 7 (concl.)

likely reason for the fall is the devaluation of the $\mathrm{E}$ in late 1967 which showed up in annual price indexes in 1968. That devaluation affects all the indexes, of course, but the coverage of the indexes for exports by destination may be lower than that of the aggregate index and the British prices may therefore have a much heavier weight in these indexes. We have no direct evidence for this explanation but it appears to be the most likely one. 
One test of the various possible assumptions is to compare, for the prices that are available, the variance across countries with the variance within countries. We made such a comparison using price changes at the 4-digit SITC level for the U.S., Germany, and Japan, calculating variances among 4-digit subgroups within 1-digit classes in each country and variances among 1 -digit classes across countries. At this level, at least, we found tile witiin-class variances in a country to be smaller than the variances among countries for the class. Thus if either country alone or commodity alone had to be used as the criterion for assigning misstrig price observations, country would be a bctter choice.

This result is somewhat surprising considering tinat ve are dealing vith tradable goods, for wich the lar of one price is of ten assumed to hold. The importance of country as a variable determining price behavior is shown in another way by a comparison of country price indexes, in Table 2. In these indexes the weights are identical for all six countries; the differences between them are therefore differences in price movements, rather than in the weighting of identical price movements. 8

For most of the period, roughly through the end of the 1960's, country differences in price movements were fairly small. The largest exceptions could be associated with changes in exchange rates such as the upward revaluation of the DM in 1961 (affecting 1961/1960 and 1962/61)

\section{8}

That is not strictly true because the absence of price data for a commodity removes that commodity from the weights. However, these are countries for which the price data are fairly complete. 
TABLE 2

Price Indexes for Manufactures (SITC 5-8)

Six Countries, OECD Export Weights

\begin{tabular}{rrrrrrrr}
\hline & \\
& U.S. & U.K. & Germany & Japan & Canada & Netherlands & Range \\
\hline & & & & & & & \\
$1954 / 53$ & 100.9 & 99.8 & 97.7 & 96.0 & NA & NA & 4.9 \\
$1955 / 54$ & 102.8 & 102.6 & 101.3 & 98.3 & NA & NA & 4.5 \\
$1956 / 55$ & 104.9 & 103.3 & 101.4 & 105.7 & NA & NA & 4.3 \\
$1957 / 56$ & 104.0 & 102.8 & 101.8 & 102.7 & 106.6 & NA & 4.8 \\
$1958 / 57$ & 101.2 & 101.3 & 100.5 & 93.4 & 100.0 & NA & 7.9 \\
$1959 / 58$ & 101.8 & 99.7 & 98.9 & 99.2 & 102.1 & NA & 3.2 \\
$1960 / 59$ & 100.3 & 100.9 & 101.1 & 99.5 & 99.6 & NA & 1.6 \\
$1961 / 60$ & 99.7 & 101.5 & 105.5 & 98.0 & 96.2 & NA & 9.3 \\
$1962 / 61$ & 99.7 & 99.5 & 102.0 & 97.7 & 95.0 & NA & 7.0 \\
$1963 / 62$ & 99.9 & 100.3 & 100.6 & 99.3 & 100.0 & 100.9 & 1.6 \\
$1964 / 63$ & 100.8 & 103.1 & 101.6 & 100.7 & 100.3 & 103.5 & 3.2 \\
$1965 / 64$ & 101.1 & 102.8 & 102.7 & 100.0 & 100.5 & 101.7 & 2.8 \\
$1966 / 65$ & 101.9 & 102.3 & 102.0 & 100.0 & 101.1 & 102.2 & 2.3 \\
$1967 / 66$ & 102.2 & 98.9 & 99.7 & 100.8 & 101.4 & 101.0 & 2.5 \\
$1968 / 67$ & 102.6 & 90.8 & 99.1 & 100.8 & 101.3 & 100.5 & 11.8 \\
$1969 / 68$ & 102.5 & 103.0 & 105.0 & 102.1 & 102.0 & 100.2 & 4.8 \\
$1970 / 69$ & 103.6 & 107.0 & 113.0 & 102.9 & 105.9 & 107.0 & 10.1 \\
$1971 / 70$ & 103.8 & 109.5 & 109.6 & 103.2 & 105.4 & 108.8 & 6.4 \\
$1972 / 71$ & 102.9 & 108.5 & 112.3 & 110.0 & 104.6 & 113.3 & 10.4 \\
$1973 / 72$ & 104.6 & 107.1 & 128.0 & 121.6 & 104.4 & 121.2 & 23.6 \\
$1974 / 73$ & 116.6 & 119.2 & 116.9 & 120.5 & 119.6 & 119.9 & 3.9 \\
$1975 / 74$ & 110.4 & 117.7 & 110.0 & 101.1 & 109.2 & 114.0 & 16.6 \\
$1976 / 75$ & 106.0 & 95.7 & 100.7 & 101.8 & 110.4 & NA & 14.7 \\
$1977 / 76$ & 106.0 & 113.8 & NA & 106.2 & 99.6 & NA & 14.2 \\
\hline
\end{tabular}


and the devaluation of the $t$ in 1967 (affecting both 1967/66 and 1968/67, but mainly the latter). ${ }^{9}$ During the 1970's, a period of much larger and more frequent exchange rate changes, the range of variation among countries was much greater, the extreme case being the range of over 23 percentage points in 1973/72. The average range during the 1950's and 1960's was 3.8 percentage points outside of the years with currency revaluations and 7.6 points in the years with revaluations, while it was over 12 per cent during the 1970's. Both the visible relation of the price indexes to specific currency revaluations during the $1960^{\prime}$ s and the wide range of country price changes during the 1970's, despite the fact that an identical set of weights has been imposed on all the countries, show that exchange rate changes were not simply offsetting current relative price movements, even for export commodities. The dissimilarity of the country price indexes also means that any formula for estimating missing price observations that relied on the law of one price or even on the similarity of price movements, without taking country differences into account, would probably be highly inaccurate.

Quality bias in lanufactures price Indest:s

One of the comments frequently made in the debate about trends in the terms of trade of manufactures relative to primary products has been that the standard price indexes for manufactures are biased upwards by their neglect of quality change, while those for primary products are not subject to the same bias. There has, however, been virtually no evidence on this subject beyond our own earlier comparison of the NBER

\section{9}

The other wide variance, in 1958/57, was not associated with any exchange rate movement but with the steep drop in Japanese prices. This was an extreme case of what appears to have been fairly regular behavior of Japanese export prices: a strong response to U.S. recessions which involved a decline in export prices or a decline relative to domestic prices. 
price series with UN unit value indexes. ${ }^{10}$ In that case, however, there were so many possible sources of divergence between the two that it was impossible to isolate the effects of quality change.

The alleged bias in manufactured goods price indexes can be divided into two parts. One is the difference we would find between a unit value index and an identically weighted index constructed using conventional specification pricing. The difference between the two would measure the effects of shifts in composition within commodity groups. That difference might represent a shift to higher or lower quality but could also represent any other change in characteristics that involved higher or lower average values per ton or per unit.

The second element of the supposed bias is the incompleteness of allowance for quality change even in indexes based on specification pricing. The quality change might take place in a characteristic of the commodity not part of the specification or, probably more important, the specification pricing method may not properly account for the change in price that takes place with the introduction of a new product, as in the substitution of jet aircraft engines for piston engines or the substitution of newer types of computers for older ones.

Here we do have some direct evidence on the second type of bias, certainly on its direction and to some extent on its size in manufactured goods price indexes. In our indexes for the United States for SITC 7 we have made the experiment of replacing a number of individual conventional price indexes at the four-digit SITC level by series that have been adjusted

10 Kravis and Lipsey (1971), Chapter 8. 
for quality changes and also of incorporating such adjusted series where there were no conventional series at all. The difference between the adjusted and unadjusted series should almost certainly be a minimum estimate of the bias from this source for several reasons. One is that the "conventional" series already included a small amount of quality adjustnent for items in SITC 7 between 1953 and 1964, where such adjustments were carried out in Kravis and Lipsey (1971). Other indexes for manufactured goods would not include such adjustments. Secondly, the corrections were performed for only eleven subgroups, all in SITC 7, accounting for about 15 per cent of exports of all manufactures and less than a third of SITC 7 exports by developed countries to developing countries. Third, we restricted the substitutions to cases where the series to be used clearly involved a specific quality adjustment, and did not use alternative series for which the adjustments involved other types of corrections, such as the more rapid introduction of new products or differences in the type of outlet from which prices were secured. 
The results of these quality corrections are shown in Table 3 . The adjusted series showed changes in manufactured goods prices that were lower (smaller increases or larger decreases) than those in the conventional series in all but two years. Over the whole period through 1976 for which we have made this calculation, the adjusted index rose 77 per cent as compared to 105 per cent for the conventional index. We would thus estimate the bias from neglect of quality change to be more than 25 per cent over the period as a whole. The average difference was over $1 / 2$ of a per cent per year.

\section{Prices of Primary Products}

Although most of the controversy about measurement has centered on the manufactured products side, there is also a considerable variance in measures of primary products prices probably not entirely due to differ-ences in coverage. The strong commercial and financial interests in primary product trade and the relative homogeneity of the products has led to the publication in countries of both origin and destination of prices for well specified product variants by both official and journalistic sources. International agencies, including the UN and IMF, have taken - tvantage of the existence of these materials to form export price indexes if primary products that go back to the 1950's. We have not developed vur own price indexes for primary products and simply report here some results using these widely avallable measures, with a small amount of reweighting to match our manufactured goods price indexes.

As in the case of manufactured goods, both unit value indexes and price indexes can be calculated. The unit value indexes, the ones most frequently compared with the corresponding manufactures series, are regularly reported by the UN and are presumably almost universal in coverage. 
TABLE 3

Comparison of Conventional and Quality-Adjusted Indexes for U.S. Prices of Manufactures OECD Export Weights

(1963=100 and each year compared to preceding year)

\begin{tabular}{|c|c|c|c|c|}
\hline & \multicolumn{2}{|c|}{$1963=100$} & \multicolumn{2}{|c|}{$\begin{array}{l}\text { Each Year Compared } \\
\text { with Preceding Year }\end{array}$} \\
\hline & Conventional & Adjusted & Conventional & Adjusted \\
\hline 1953 & 86.1 & 94.4 & & \\
\hline 1954 & 86.9 & 94.3 & 100.9 & 99.9 \\
\hline 1955 & 89.3 & 95.6 & 102.8 & 101.4 \\
\hline 1956 & 93.7 & 98.7 & 104.9 & 103.2 \\
\hline 1957 & 97.4 & 101.8 & 104.0 & 103.1 \\
\hline 1958 & 98.6 & 102.3 & 101.2 & 100.5 \\
\hline 1959 & 100.4 & 102.2 & 101.8 & 99.9 \\
\hline 1960 & 100.7 & 101.8 & 100.3 & 99.6 \\
\hline 1961 & 100.4 & 101.3 & 99.7 & 99.5 \\
\hline 1962 & 100.1 & 100.8 & 99.7 & 99.5 \\
\hline 1963 & 100.0 & 100.0 & 99.9 & 99.2 \\
\hline 1964 & 100.8 & 100.4 & 100.8 & 100.4 \\
\hline 1965 & 101.9 & 101.1 & 101.1 & 100.7 \\
\hline 1966 & 103.8 & 102.3 & 101.9 & 101.2 \\
\hline 1967 & 106.1 & 103.9 & 102.2 & 101.5 \\
\hline 1968 & 108.9 & 105.6 & 102.6 & 101.7 \\
\hline 1969 & 111.6 & 108.3 & 102.5 & 102.5 \\
\hline 1970 & 115.6 & 111.6 & 103.6 & 103.1 \\
\hline 1971 & 120.0 & 115.5 & 103.8 & 103.5 \\
\hline 1972 & 123.5 & 118.4 & 102.9 & 102.5 \\
\hline 1973 & 129.2 & 124.1 & 104.6 & 104.8 \\
\hline 1974 & 150.6 & 144.1 & 116.6 & 116.1 \\
\hline 1975 & 166.3 & 158.4 & 110.4 & 109.9 \\
\hline 1976 & 176.2 & 166.9 & 106.0 & 105.4 \\
\hline
\end{tabular}


For price indexes, the problems posed in their construction are less formidable than those for manufactures, but still not negligible. Both the UN and the IMF indexes aim at worldwide coverage of price movements and are Type $E$ measures. A Type E index may be advantageous for primary product prices if they come close to obeying the law of one price, at least with respect to price changes. If, for example, Brazilian iron ore and coffee export prices each moved very similarly to prices of the same commodities abroad but changed relative to each other, a Type E index might be more appropriate than the Type A index we have used for manufactures. The UN index is broader in comnodity coverage, including dairy products, forest products and fuels, none of which is in the IIF index. Also with 61 primary commodities and 6 nonferrous metals the UN index can obtain fuller coverage for sectors included in both indexes: for example, it includes bananas, oranes, lemons, grapefruits, apples, tomatoes, onions and pepper whereas the only fruit or vegetable in the IMF index is bananas. Both indexes are computed with a Laspeyres formula, the Uiv usinc country and conmodity export weights. The UN series starts with 1950 and is a series of linked indexes with the early years employing 1953 export weights and the most recent years those of 1975. The IrF series begins with 1957 and is based on 1968-70. Both indexes aim at export prices but rely on a mixture of export, import and domestic price series.

Table 4 summarizes the primary goods price measures and compares them with unit values, both including and excluding fuels. The chief differences in the behavior of the IMF and UN price indexes, each taken in its most comprehensive form, is attributable to the inclusion of fuel in the UN index and its exclusion from that of the IMF. Given the huge increases 
TABLE 4

Measures of Primary Goods Prices

(1963=100)

\begin{tabular}{|c|c|c|c|c|c|}
\hline & \multirow{2}{*}{\multicolumn{2}{|c|}{$\begin{array}{l}\text { UN Unit Value Indexes: } \\
\text { Exports by Developing } \\
\text { Areas to Developed Areas }\end{array}$}} & \multicolumn{3}{|c|}{ Export Price Indexes } \\
\hline & & & \multirow{2}{*}{$\begin{array}{c}\text { IMF } \\
\text { Food, } \\
\text { Beverages, } \\
\text { and Agri- } \\
\text { cultural } \\
\text { Raw } \\
\text { Materials } \\
\text { (3) }\end{array}$} & \multicolumn{2}{|c|}{$\begin{array}{ll} & \text { UN } \\
\text { Primary Commodities }\end{array}$} \\
\hline & $\begin{array}{l}\text { Food and } \\
\text { Raw } \\
\text { Materials } \\
\text { (1) }\end{array}$ & $\begin{array}{l}\text { Food, Raw } \\
\text { l:aterials } \\
\text { and Fuels } \\
\quad(2)\end{array}$ & & $\begin{array}{l}\text { Including } \\
\text { Fuels } \\
\text { (4) }\end{array}$ & $\begin{array}{l}\text { Excluding } \\
\text { Crude } \\
\text { Petroleum } \\
\text { (5) }\end{array}$ \\
\hline 1953 & 110 & 108 & & 110 & \\
\hline 1954 & 114 & 111 & & 115 & \\
\hline 1955 & 110 & 110 & & 108 & \\
\hline 1956 & 108 & 109 & & 108 & \\
\hline 1957 & 111 & 112 & 111 & 109 & \\
\hline 1958 & 104 & 108 & 101 & 103 & \\
\hline 1959 & 101 & 104 & 99 & 100 & \\
\hline 1960 & 102 & 103 & 98 & 99 & \\
\hline 1961 & 98 & 100 & 93 & 97 & \\
\hline 1962 & 95 & 97 & 92 & 96 & \\
\hline 1963 & 100 & 100 & 100 & 100 & \\
\hline 1964 & 105 & 103 & 102 & 103 & \\
\hline 1965 & 101 & 100 & 96 & 103 & \\
\hline 1966 & 102 & 100 & 97 & 104 & \\
\hline 1,967 & 99 & 98 & 95 & 101 & \\
\hline 1968 & 98 & 98 & 93 & 100 & \\
\hline 1969 & 102 & 101 & 100 & 104 & \\
\hline 1970 & 105 & 104 & 103 & 107 & 107 \\
\hline Iy71 & 103 & 111 & 100 & 118 & 112 \\
\hline $1 \geqslant ? 2$ & 112 & 121 & 118 & 132 & 125 \\
\hline 1973 & 145 & 160 & 184 & 198 & 191 \\
\hline .1974 & 206 & 334 & 240 & 357 & 244 \\
\hline 1975 & 195 & 337 & 198 & 347 & 228 \\
\hline i976 & 216 & 363 & 225 & 367 & 241 \\
\hline 1977 & 256 & 410 & 280 & 406 & 269 \\
\hline
\end{tabular}


Notes to TABLE 4

Col. (1) and (2): UN unit value indexes for exports by developing countries to developed countries from Monthly Bulletin of Statistics, Nov. 1965, Dec. 1971, June 1977 and July 1980. Separate indexes for Foods and beverages (SITC 0 and 1), Raw materials except foods (SITC 2 and 4 ) and Fuels (SITC 3 ) were combined by us using the average of 1960 and 1965 weights. For the index excluding fuels the weights were 53.2 per cent for SITC 0 and 1 and 46.8 per cent for SITC 2 and 4 . For the index of all primary products the veights were 34.9 per cent for SITC 0 and $1,30.6$ per cent for SITC 2 and 4 , and 34.5 per cent for SITC 3 .

Col. (3): IMF price indexes for foods, beverages and agricultural raw materials combined by us with weights of 68.8 per cent for foods and beverages and 31.2 per cent for agricultural raw materials.

Col. (4) and (5): UN price indexes for all primary commodities and primary comnodities except crude petroleum from Price Movements of Basic Comnodities in International Trade: 1950-1970, Statistical Papers, Series M, No. 29, Rev. 1/Add. 1, p. 7 and Methods Used in Compiling the UN Price Indexes for Basic Commodities in International Trade, Statistical Papers, Series M, No. 29, Rev. 2, pp. 31 and 108. The series excluding crude petroleum was linked to the one including it at 1970 . 
In petroleum prices beginning in 1973, it is not surprising that the UN shows the overall index at 406 in 1977 while the overall IMF index is only 280. When petroleum is excluded, the UN 1977 index is 269, not far from the IIF index and even a little below 1t. Before 1970, when fuel prices did not behave so exceptionally, the two indexes do not disagree on the broad development of primary product prices. From 1957 to 1970 the annual index numbers in each series moved up and down without a clear trend and never strayed outside of a 10 per cent range on either side of the mean for the period.

From the comparison between the most comprehensive price index (Col. 4) and unit value index (Col, 2) we find no support for the idea suggested by Spraos (1980) that unit value indexes for primary goods pxports are as likely to suffer from upward bias due to quality change as those for manufactured goods. If they do, they should tend to increase relative to indexes based on price data, but no such tendency is visible here; the trends are very similar. We cannot conclude that the unit value indexes are not biased, since there are other differences between the two types of indexes, such as in coverage and weiginting and in the reference dates of the prices being reported that we have not corrected for. However, we can say that these indexes, both produced by the UN, show no evidence of upward bias in unit value indexes for primary commodities.

\section{Terms of Trade}

Since we have our own price measures only for manufactured goods the best measures of the terms of trade we can calculate are based on the comparison of these with the UN and IMF price indexes for primary products. 
We can then compare these with the corresponding estimates of terms of trade changes based on unit values in both numerator and denominator.

Terms of trade measures for developed-country manufactured products relative to developing-country primary products based on price, rather than unit value, data appear in Table 5. The terms of trade moved in favor of manufactures between 1953 and the end of the 1960's or 1970. The manufactures-primary product terms of trade (Col. 3) rose gradually but fairly steadily, from 83 in 1953 to 105 in 1967 and 1968 and to 106 in 1970 (with $1963=100$ ). This gain of 28 per cent was, however, quickly dissipated in the ensuing years; by 1974 the index was down to 48, its lowest point in our table, and it was only 51 in 1977. When the price of petroleum is excluded from primary products, the index of the terms of trade between manufactures and primary products (Col. 2) rises until 1972, but it then declines by a third between 1972 and 1977. Thus the decline in manufactures terms of trade in the 1970's was far from being a result solely of rising oil prices. however, the comparison with primary products excluding crude petroleum shows manufactured goods terms of trade in 1973-77 only 10 per cent below 1953-57 while the comparison with all primary products shows them more than a third lower in the latter period.

We mentioned earlier the suspicion that the commonly used manufacturedgoods unit value and price indexes might have been biased by the failure to take account of quality improvement in manufactures and we presented what we thought to be a minimum estimate of such bias for the United States. An approximation of the probable effect of such bias on our terms of trade calculation may be based on the difference between the adjusted and unadjusted price indexes for U.S. manufactures by assuming that the quality adjustment 
TABLE 5

Indexes of Terms of Trade Between Manufactures Exports of Developed Countries to Developing Countries and Primary Products Price Data

\begin{tabular}{|c|c|c|c|c|}
\hline & \multicolumn{2}{|c|}{ Manufactures } & \multirow{2}{*}{\multicolumn{2}{|c|}{$\frac{\text { Relative to Prices of }}{\text { All Primary Commoditi }}$}} \\
\hline & \multicolumn{2}{|c|}{ Primary Products excl. fuels } & & \\
\hline & $\begin{array}{l}\text { IIF: Foods, } \\
\text { Beverages, } \\
\text { and Agri- } \\
\text { cultural Raw } \\
\text { Materials } \\
\text { (1) }\end{array}$ & $\begin{array}{l}\text { UN--Primary } \\
\text { Commodities, } \\
\text { Excluding } \\
\text { Crude } \\
\text { Petroleum } \\
\text { (2) }\end{array}$ & $\begin{array}{l}\text { With Con- } \\
\text { ventional } \\
\text { Index for } \\
\text { Manu- } \\
\text { factures } \\
\text { (3) }\end{array}$ & $\begin{array}{c}\text { With Qualit } \\
\text { Change } \\
\text { Correctior } \\
\text { for } \\
\text { Manufacture } \\
(4)\end{array}$ \\
\hline 1953 & & 83 & 83 & 91 \\
\hline 1954 & & 79 & 79 & 86 \\
\hline 1955 & & 86 & 86 & 92 \\
\hline 1956 & & 89 & 89 & 94 \\
\hline 1957 & 90 & 91 & 91 & 95 \\
\hline 1958 & 98 & 96 & 96 & 100 \\
\hline 1959 & 101 & 100 & 100 & 102 \\
\hline 1960 & 102 & 101 & 101 & 102 \\
\hline 1961 & 108 & 104 & 104 & 105 \\
\hline 1962 & $10 y$ & 104 & 104 & 105 \\
\hline 1963 & 100 & 100 & 100 & 100 \\
\hline 1964 & 100 & 99 & 99 & 99 \\
\hline 1965 & 107 & 100 & 100 & 99 \\
\hline 1966 & $10 \varepsilon$ & 101 & 101 & 100 \\
\hline 1967 & 111 & 105 & 105 & 103 \\
\hline 1968 & 113 & 105 & 105 & 102 \\
\hline 1969 & 108 & 103 & 103 & 100 \\
\hline 1970 & 110 & 106 & 106 & 102 \\
\hline 1971 & 121 & 108 & 102 & 98 \\
\hline 1972 & 110 & 116 & 98 & 94 \\
\hline 1973 & 79 & 76 & 73 & 70 \\
\hline 1974 & 71 & 70 & 48 & 46 \\
\hline 1975 & 96 & 83 & 55 & 52 \\
\hline 1976 & 86 & 80 & 53 & 50 \\
\hline 1977 & 74 & 78 & 51 & NA \\
\hline
\end{tabular}

Sources: Col. (1): Table 1, Col. (1) $\div$ Table 4, Col. (3).

Col. (2): Table 1, Col. (1) $\div$ Table 4, Col. (4), through 1970, and (5), 1971-77.

Col. (3): Table 1, Col. (1) $\div$ Table 4, Col. (4).

Col. (4): Col. (3) multiplied by the ratio of the adjusted to the conventional index in Table 3 . 
estimated for the United States in Table 3 may be applied proportionately to our "world" (six-country composite) price index for manufactures. That approximation, shown in column (4), suggests that the period of rising terms of trade for manufactures was very brief: mainly from 1953 to the early 1960's. In fact, aside from a couple of higher levels in 1961 and 1962, the terms of trade of manufactures by this measure, were virtually unchanged from 1958-59 through 1969-70. After that they fell very sharply as did the uncorrected indexes. Thus the main effect of the quality correction is to substantially dampen, but not completely offset, the decline in the terms of trade for primary products between 1953 and 1970 . It has little impact on our impression of later developments.

The effect on terms-of trade calculations of using unit values instead of prices can be observed by comparing Table 5 with Table 6 , which presents some unit value measures. The comparison is summarized in the text table, below. It shows that betwicen 1953 and 1976 the price data, even without

Terms of Trade Between Manufactures Exports of Developed Countries and Primary Products: 1976/1953

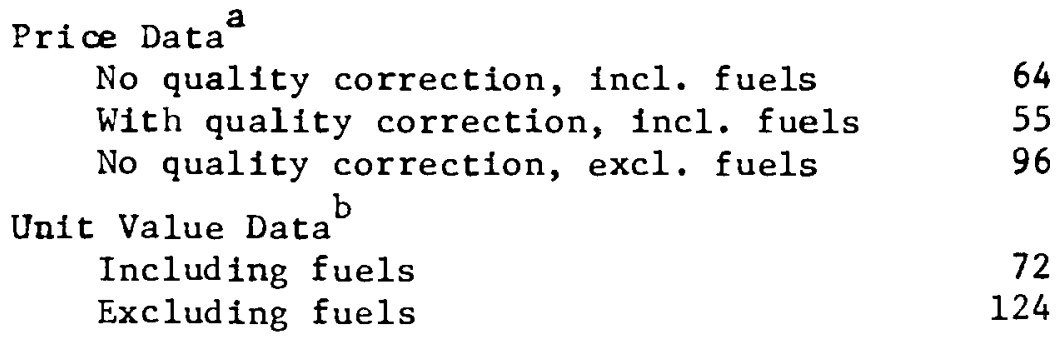


TABLE 6

Indexes of Terns of Trade Between Manufactures Exports of Developed Countries and Primary Product Exports by Developing Countries to Developed Countries

Unit Value Data

\begin{tabular}{|c|c|c|c|c|}
\hline & \multicolumn{2}{|c|}{$\begin{array}{c}\text { Total Manufactures } \\
\text { Exports }\end{array}$} & \multicolumn{2}{|c|}{$\begin{array}{l}\text { Manufactures Exports } \\
\text { by Developed to } \\
\text { Developing Countries }\end{array}$} \\
\hline & $\begin{array}{l}\text { Primary } \\
\text { Exports } \\
\quad(1)\end{array}$ & $\begin{array}{l}\text { Primary } \\
\text { Exports } \\
\text { exc. Fuels } \\
\text { (2) }\end{array}$ & $\begin{array}{l}\text { Primary } \\
\text { Exports } \\
\text { (3) }\end{array}$ & $\begin{array}{l}\text { Primary } \\
\text { Exports } \\
\text { exc. Fuels } \\
\text { (4) }\end{array}$ \\
\hline 1953 & 85 & 84 & 87 & 85 \\
\hline 1954 & 82 & 80 & 82 & 80 \\
\hline 1955 & 83 & 83 & 83 & 83 \\
\hline 1956 & 87 & 88 & 86 & 87 \\
\hline 1957 & 88 & 88 & 87 & 88 \\
\hline 1958 & 90 & 93 & 91 & 95 \\
\hline 1959 & 92 & 95 & 93 & 96 \\
\hline 1960 & 95 & 96 & 97 & 98 \\
\hline 1961 & 99 & 101 & 100 & 102 \\
\hline 1962 & 102 & 104 & 102 & 105 \\
\hline 1963 & 100 & 100 & 100 & 100 \\
\hline 1954 & 98 & 96 & 99 & 97 \\
\hline 1965 & 103 & 102 & 105 & 104 \\
\hline 1966 & 106 & 104 & 106 & 104 \\
\hline 1967 & 109 & 108 & 109 & 108 \\
\hline 1968 & 109 & 109 & 102 & 102 \\
\hline 1969 & 109 & 108 & 100 & 99 \\
\hline 1970 & 112 & 111 & 107 & 106 \\
\hline 1971 & 112 & 120 & 108 & 116 \\
\hline 1972 & 111 & 120 & 109 & 118 \\
\hline 1973 & 98 & 108 & 99 & 109 \\
\hline 1974 & 57 & 92 & 59 & 95 \\
\hline 1975 & 63 & 109 & 67 & 116 \\
\hline 1976 & 59 & 100 & 63 & 105 \\
\hline 1977 & 57 & 91 & 60 & 96 \\
\hline
\end{tabular}

Sources: Col. (1): Table 1, Col. (2) $\div$ Table 4, Col. (2).

Col. (2): Table 1, Col. (2) $\div$ Table 4, Col. (1).

Col. (3): Table 1, Col. (3) $\div$ Table 4, Col. (2).

Col. (4): Table 1, Col. (3) $\div$ Table 4, Col. (1). 
any correction for quality change in manufactures, indicate a decrease in the terms of trade of manufactures relative to all primary products (36 per cent) almost a quarter greater than that suggested by the unit values (28 per cent). With that correction for quality change the price data suggest a fall in manufactures terms of trade ( 45 per cent) more than 50 per cent greater. The difference between price and unit value measures of terms of trade is even larger for primary products other than fuels. The unit values show a substantial rise in the terms of trade of manufactures while the price indexes show a fail.

The direction of terms-of-trade changes an investigator finds is sensitive to the period of his study. If we had stopped our calculations at 1970 we would have found increases in the terms of trade for manufactured goods whether we measured them by prices or by unit values and with or without fuels included among primary products. Fowever, quality-corrected neasures of the terms of trade of manufactures would have shown only about half as large a gain as the other indexes. The direction of this apparent bias due to the neglect of quality change in manufactures seems to be impervious to changes in the span of years examined.

\section{Historical Perspective}

In view of the many historical generalizations that have been made about the terms of trade between manufactured goods and primary products, it is of some interest to try to place the experience of the past 25 years or so in historical perspective. Unfortunately, the tools for doing so are even cruder than the series we have used for the recent past. All of the available series, at least for manufactures, have as their basic ingrediients the same unit value data, and differ only in weighting, in product 
and geographical coverage, in the degree of disaggregation used in calculation, and in the years at which various versions of the series were linked. To the extent that there are biases or inaccuracies in unit value series, as we have suggested, they are incorporated in those we must rely on for earlier years.

The unit value measures in Table 7 seem to be the closest we can come to the concepts we use for later years with respect to commodity and country coverage. They are unit value indexes derived from Kindleberger (1956) and from Maizels (1963). Those from Kindleberger are for Industrial Europe's exports of manufactured products to areas outside Europe and the United States and for Industrial Europe's imports of food, drink, and tobacco and raw materials from the same areas. They are for six widely spaced years from 1872-1952 and use end-year trade weights for each period. We used estimates for the same weights in combining them for Table 7 . The indexes from Maizels (1963) are for exports of manufactures to the world by European countries, the United States, Canada, Japan, and India. The Maizels indexes cover a set of periods similar to Kindleberger's but beginning only in 1899. They were published with both end-year and beginning-year weights for each period but we have used only the former for comparability with the Kindleberger indexes for primary products.

As compared with other available indexes, both of these have the advantage of covering a long span of years using a common method of calculation across both periods and countries, as far as that could be done with the data as published. The Kindleberger indexes refer specifically to manufactures exports by developed countries to developing countries and developing-country exports of primary products to developed countries. The Maizels indexes are more like our own in that they are for exports to the world, assuming in effect that price movements are the same across all destinations for a 


\section{TAB:E 7}

Unt Value Indexes and Terms of Trade Between Manufactured Exports and Primary Imports to Industrial Europe from Developing Areas

$1913=100$

\section{Unit Value Indexes}

Manufactures

$\begin{array}{lll}\text { Kindleberger Maizels } & \text { Primary } \\ \text { Products }\end{array}$

(1)

(2)
(3)

Terms of Trade
Based on Manufactures
Price Indexes from
Kindleberger Maizels

(4)

(5)

\begin{tabular}{|c|c|c|c|c|c|}
\hline 1872 & 161 & $\mathrm{NA}_{h}$ & 121 & 133 & NA \\
\hline $1899-1900$ & $103^{a}$ & $88^{b}$ & $82^{a}$ & 126 & 107 \\
\hline 1913 & 100 & 100 & 100 & 100 & 100 \\
\hline $1928-29$ & $138^{c}$ & $133_{\mathrm{f}}^{\mathrm{d}}$ & $134^{\mathrm{c}}$ & 103 & 99 \\
\hline $1937-38$ & $145^{\mathrm{e}}$ & $118^{\mathrm{f}}$ & $88^{\mathrm{e}}$ & 165 & 134 \\
\hline $19 ১ 0$ & 260 & 205 & 204 & 127 & 100 \\
\hline 1952 & 315 & & 237 & 133 & \\
\hline 1953 & 302 & 243 & 227 & 133 & \\
\hline 1955 & & 244 & & & 107 \\
\hline $1900 / 1872$ & 64 & NA & 68 & 94 & NA \\
\hline $1913 / 1899-1900$ & 97 & 114 & 121 & 80 & 94 \\
\hline $1928-29 / 1913$ & 138 & 133 & 134 & 103 & 99 \\
\hline $1937-38 / 1928-29$ & 105 & 89 & 65 & 162 & 137 \\
\hline $1950 / 1937-38$ & 179 & 173 & 232 & 77 & 75 \\
\hline $1953 / 1950$ & 116 & 119 & 111 & 105 & 107 \\
\hline $\begin{array}{l}1953 / 1872 \\
1953 / 1899-1900\end{array}$ & $\begin{array}{l}188 \\
293\end{array}$ & $\begin{array}{r}\mathrm{NA} \\
276\end{array}$ & $\begin{array}{l}188 \\
277\end{array}$ & $\begin{array}{l}100 \\
106\end{array}$ & $\begin{array}{r}N A \\
100\end{array}$ \\
\hline
\end{tabular}


Notes to TABLE 7
1900
b
1899
1928
d 1929
e 1938
f
1937
Columns (1) and (3): A11 except 1950 and 1953 from Kindleberger (1956), pp. 49-50, 59,61, 63, 65. 1950 and 1953 extrapo- 1 ated from 1952 by UN unit value indexes reproduced in cuddy $(1976), \mathrm{p} .125$.
Manufactures: Unit values for Industrial Europe exports to Areas of recent settlement and 0 ther, except Europe and the United States, of six groups of manufactured products. Values of exports were given for each product group and each area, but not product group by area. We estimated the appropriate weights by assuming that the area break- down was identical across product groups. Weights are end-of-period values for each period.
Primary products: Unit values for Industrial Europe imports from Areas of recent settlement and Other, except Europe and the United States, of Food, drink and tobacco and Raw materials. Weights were estimated as for exports of manufactures.
Column (2): A11 except 1953 from Maizels (1963), pp. 508-512. 1953 interpolated between $195 \mathrm{C}$ and 1955 by UN unit value index for Manufactured goods reproduced in Cuddy (1976), p. 125. Unit values for manufactures exports to al1 destina- tions by the countries covered by Kindleberger plus Canada, the United States, India, and Japan.
Column (4): $\operatorname{Col} .(1) \div \operatorname{Col}$. (3).
Column (5) $\operatorname{Col} .(2) \div \operatorname{Col}$. (3). 
particular product from a particular exporter.11 Two drawbacks

11

For a discussion and justification of this assumption see Maize1s (1957).

of the Kindleberger indexes, aside from the probably excessive degree of aggregation discussed by both Kindleberger and Maizels, are the omission of the United States as an exporter and the fact that the primary product prices include freight, since they are derived from import values. Although Maizels includes India as an exporter, its weight is too low to have any substantial effect on the index for all manufactures.

The picture of trends in terms of trade shown by the two indexes from 1900 to the beginning of our series in 1953 is similar. The terms of trade between manufactured goods and primary products were roughly the same in 1953 as in 1900 , but the Kindleberger series showed much wider fluctuations. In addition the Kindleberger series indicated little change in the terms of trade of manufactured products between 1872, when they began, and 1900, and thus no real trend between 1872 and 1953 . Perhaps the main point to be emphasized is the very wide range of the fluctuations of the terms of trade and, as a consequence, the dependence of any impression about trends on the choice of beginning and end years. For example, 1938, the final year of Hilgerdt's League of Nations study, ${ }^{12}$ was the most unfavorable for primary products in the

12 League of Nations (1945). 
whole period after 1872, and it is not surprising that he found a long term downward trend in primary product prices. The early 1950's, on the other hand, followed a large recovery of primary product prices, and a period of worry about raw material shortages. It is thus not surprising that studies of terms of trade since the early $1950^{\prime}$ s tended, until recently, to again find downward trends in relative prices of primary products. Similarly, it is understandable that around the World War I years, the long-term trend was thought by many to favor primary producers.

\section{Conclusion}

These calculations indicate that the prices of manufactured goods exported by developed countries to developing countries have risen over twenty years or so by considerably less than is shown by the generally used UN unit value indexes: something like 75 per cent rather than 140 per cent. Furthermore, the decline in terns of trade for these goods relative to primary products has been almost 50 per cent. substantially greater than one might calculate from unit value indexes, which suggest a fall of only about one third.

The difference between our estimate of the decline between 1953 and 1976 in the terms of trade of manufactures relative to primary products (45 per cent) and that based on unit values (28 per cent) is composed of several elements. Mostly they are aspects of the manufactured goods price measurement, which has been the focus of our research, although if a different time span were used, there would be some larger effect of our use of prices instead of unit values for primary products. One component is some mixture of differences in index number formulas, country coverage, 
and the use of price data rather than unit values, of which we think the last is the main influence. That part accounted for about half of the difference. The second half was the result of a minimum estimate of quality bias in the manufactured goods price index.

These are all rough calculations, sensitive to choices of end-years and other factors. We plan further refinement of them, but so $f$ ar they do suggest the likelihood that the usual estimates of the rise in manufactured goods prices and the terms of trade of manufactured goods relative to primary products are seriously biased upwards.

It is important to remind ourselves in all these discussions of the terms of trade that, as has often been pointed out, and despite the apparent impilications that have been drawn, the net barter terms of trade is not a welfare measure, and that its divergence from a welfare measure is particularly great over long periods. The reason we would emphasize is that long-term changes are dominated by shifts in supply: major changes in productivicy which make the net barter terms of trade depart from the single factoral terms of trade, which could make a stronger claim to be welfare measures. Ilowever, both of these measures suffer from the added defect that they ignore quantity changes and would treat as "favorable," for example, a rise in export price which drives the exporter almost, but not completely, out of export markets.

Perhaps the only safe conclusion about very long-run trends in either direction is that the evidence for their existence is weak. There is very little foundation for historical "laws" that specify the inevitability of movements in either direction in the terms of trade between these two sets cf products. If a speculation is to be provided, the safest one would appear to be that any apparent trend is likely to be reversed. The serious content of this " 1 aw" is to remind us of the self-limiting feature inherent in sustained shifts in the relative price movements of any pair of broad categories of goods. The relative prices of computers can, of course, sink very low and that of petroleum can go very high. However, when one whole class of goods such as primary products is compared with another such as manufactures--both having very varied and widely spread uses throughout the world economy--supply and demand factors tend to operate so as to limit the extent and duration of relative price shifts. Eventually producers are driven off and/or drawn in while consumers are affected oppositely, and eventually relative price movements shift in the opposite direction. 
Laws of improving or worsening terms of trade for manufactures or for prinary products are usually based on two dangerous suppositions: 1. It is possible to predict the relative behavior of demand and supply for the two groups of products; and 2 . Responses to the changes in these relative demand and supply conditions will take the form of permanent price shifts rather than quantity shifts. Over the long run quantities can change a lot, and trends turn out to be fitted to arbitrary points in long, irregular, and probably unpredictable cycles. 


\section{Appendix}

Sources of Data

The set of price data we gave priority to are the international price indexes for metals, metal products, machinery, and transport equipment for the U.S., the U.K., Germany, and Japan, 1953, 1957, and 1961-64, from Kravis and Lipsey (1971). These were interpolated by various other series, mainly the types mentioned below, as described in Kravis and Lipsey (1972), to give continuous series for the period from 1953 through 1964. The second priority was given to the official export price indexes published by various countries. The German price data at the commodity level appear in Statistisches Bundesamt, Preise, Lbhne, Wirtschaftsrechnungen, Reihe 1, Preise und Preisindizes fur Aussenhandelsguter. A brief description is given in Angermann (1980), and in articles in Wirtschaft und Statist1k such as Rostin (1974). The Japanese export price data are published in the Price Indexes Annual, earlier the Export and Import Price Indexes Annual, of the Bank of Japan. The U.S. export price data are from releases of the U.S. Bureau of Labor Statistics entitled, "U.S. Import and Export Price Indexes." A brief description of these is given in Comparisons of U.S., German, and Japanese Export Price Indexes, BLS Bulletin 2046, 1980.

Export price data for other countries were more fragmentary. Two publications of the Central Bureau of Statistics of the Netherlands, Maandstatistiek van de Binnenlandse Handel and Bijvoegsel Maandstatistiek van de Prijzen, provided export price data with incomplete but increasing coverage. 
For the U.K. there are virtually no export price data outside the period of the price competitiveness study. The exception is a set of export price indexes for products in SITC 7 for 1976 through 1979, part of an experimental program that was later discontinued.

For Canada, our data consist entirely of domestic prices: wholesale price indexes at a detailed level from tapes provided by Statistics Canada.

Domestic price data for the U.S. were price series at the most detailed level from a BLS Wholesale Price Index tape. For the U.K., some individual series were collected from publications of the Board of Trade and the Department of Trade and Industry. Hovever, the U.K. does not publish individual series for most machinery or "engineering" groups. For these, we used a set of indexes at the two-digit SITC level calculated for us by the Board of Trade from detailed price data using OECD weights we supplied. For later years, we could not obtain these series and were obliged to use a similar set of two-digit indexes calculated by the Department of Trade and Industry based on U.K. export weights.

The German domestic price indexes are individual series published in Preise, Lbhne, Wirtschaftsrechnungen, Reihe 3, Preise und Preisindizes fur industrielle Produkte, Index der Erzeugerpreise and Reihe 8, Index der Grosshandelsverkaufspreise (Statistisches Bundesamt, Wiesbaden). The Japanese domestic price indexes are also individual series from the Price Indexes Annual and the Wholesale Price Indexes Annual published by the Bank of Japan. 
The other main set of data are the hedonic price indexes substituted for conventional price series in our calculation of the quality-adjusted price index. These indexes are from a number of sources but were, with one exception, collected by Robert J. Gordon for his manuscript on The Measurement of Durable Goods Prices. The other index that was used was for aircraft, taken from kobert J. Gordon, "Energy Efficiency, User Cost Change, and the Mleasurement of Durable Goods Prices," NBER Working Paper No. 408, November 1979. The hedonic price indexes were for the following SITC subgroups, with weights as indicated.

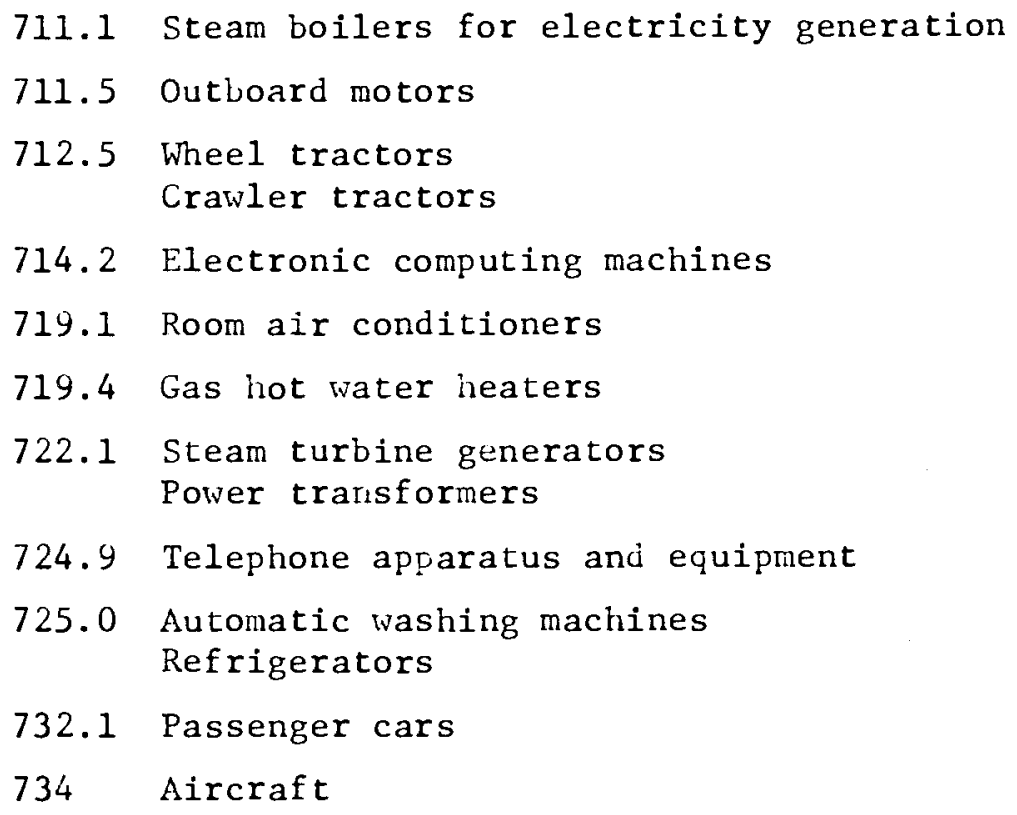

Weights: Value of exports by developed countries to developing countries in each subgroup as per cent of such exports for all manufactures, SITC 7, and two-digit classes

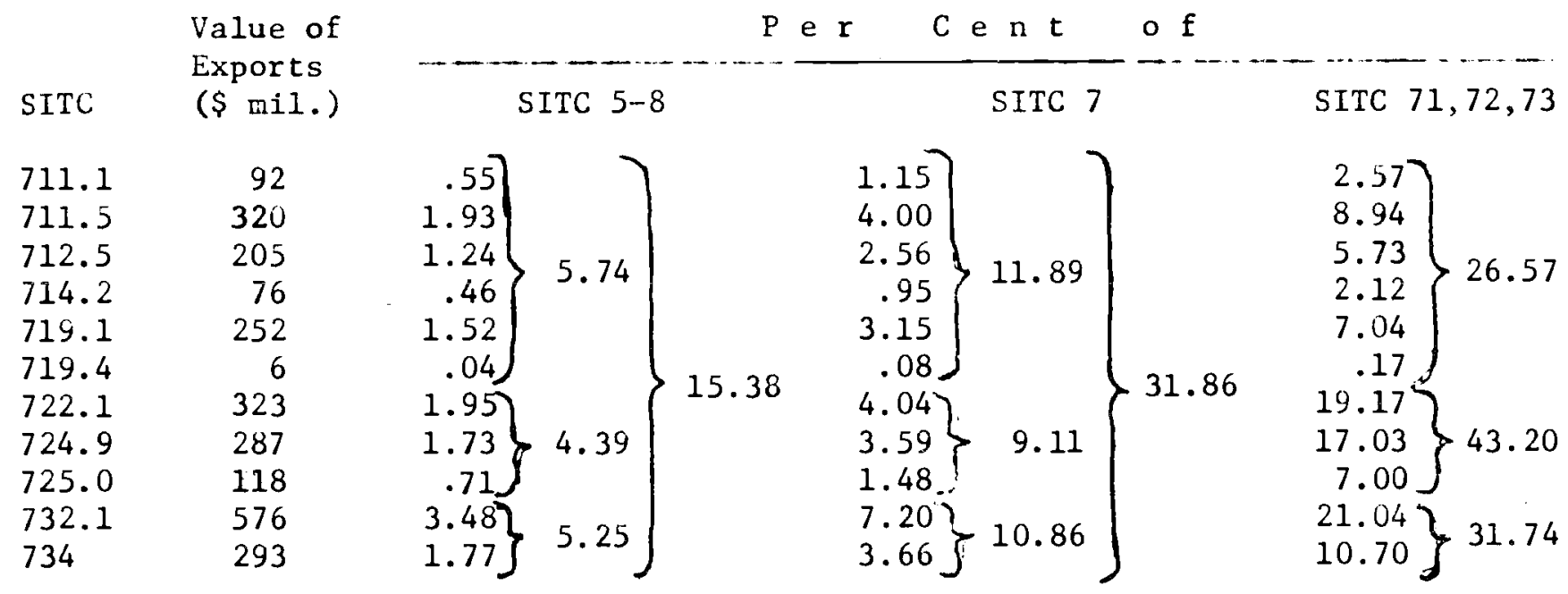


TABLE $A-1$

Comparison of Type A and Type B NBER Price Indexes for Manufactures

(1963=100 and each year compared with previous one)

\begin{tabular}{|c|c|c|c|c|}
\hline & \multicolumn{2}{|c|}{$1963=100$} & \multicolumn{2}{|c|}{$\begin{array}{l}\text { Each Year Compared } \\
\text { With Previous Year } \\
\text { (Per cent change) }\end{array}$} \\
\hline & Type A & Type B & Type A & Type B \\
\hline 1953 & 91.7 & 91.7 & - & - \\
\hline 1954 & 91.0 & 90.8 & -0.8 & -1.0 \\
\hline 1955 & 92.5 & 92.2 & +1.6 & +1.6 \\
\hline 1956 & 96.3 & 96.3 & +4.1 & +4.4 \\
\hline 1957 & 99.4 & 98.9 & +3.2 & +2.7 \\
\hline 1958 & 99.1 & 98.5 & -0.3 & -0.4 \\
\hline 1959 & 99.5 & 99.3 & +0.4 & +0.8 \\
\hline 1960 & 99.9 & 99.6 & +0.4 & +0.3 \\
\hline 1961 & 100.5 & 100.2 & +0.6 & +0.6 \\
\hline 1962 & 100.0 & 99.6 & -0.5 & -0.6 \\
\hline 1963 & 100.0 & 100.0 & 0 & +0.4 \\
\hline 1964 & 101.5 & 101.6 & +1.5 & +1.6 \\
\hline 1965 & 103.0 & 103.2 & +1.5 & +1.6 \\
\hline 1966 & 104.8 & 105.1 & +1.7 & +1.8 \\
\hline 1967 & 105.6 & 106.1 & +0.8 & +1.0 \\
\hline 1968 & 104.7 & 105.1 & -0.9 & -0.9 \\
\hline 1969 & 107.6 & 108.7 & +2.8 & +3.4 \\
\hline 1970 & 113.8 & 115.2 & +5.8 & +6.0 \\
\hline 1971 & 120.7 & 122.2 & +6.0 & +6.1 \\
\hline 1972 & 129.4 & 131.0 & +7.2 & +7.2 \\
\hline 1973 & 145.1 & 147.6 & +12.2 & +12.7 \\
\hline 1974 & 171.4 & 173.9 & +18.1 & +17.8 \\
\hline 1975 & 189.2 & 192.8 & +10.4 & +10.9 \\
\hline 1976 & 193.3 & 197.8 & +2.2 & +2.6 \\
\hline 1977 & 208.6 & 214.2 & +7.9 & +8.3 \\
\hline
\end{tabular}




\section{List of References}

Angermann, Oswald (1980), "External Terms of Trade of the Federal Republic of Germany using Different Methods of Deflation," Review of Income and Wealth, Series 26, No. 4. Dec.

Baldwin, Robert E. (1955), "Secular lovements in the Terms of Trade," American Economic Review, May.

Cuddy, J.D.A. (1976), International Price Indexation, Saxon House/Lexington Books.

Ellsworth, P.T. (1956), "The Terms of Trade Between Primary Producing and Industrial Countries," Inter-American Economic Affairs, Vol. X, Sumner.

Haberler, Gottfried (1959), International Trade and Economic Development, Cairo, National Bank of Egypt, Fiftieth Anniversary Commemoration Lectures.

(1961), "Terms of Trade and Economic Development," in Howard S. Fllis (Ed.), Economic Development for Latin America, Macmillan, London.

Hansen, Bent and Edward Lucas (1981), "The Econometric Approach to Index Numbers," Unpublished paper.

Jevons, W. Stanly (1866), The Coal Ouestion, Hacmillan, London.

Keynes, J.M. (1912), "Return of Estimated Value of Foreign Trade of United Kingdom at Prices of 1900," Economic Journal, Vol. 22, io. 88.

Kindleberger, Charles P. (1956), The Terms of Trade: A European Case Study, irew York.

Kravis, Irving B. and Robert E. Lipsey (1971), Price Competitiveness in World Trade, NBER.

(1972), "The Elasticity of Substitution as a Variable in World Trade," in Don Daly (Ed.), International Comparisons of Prices and Output, Studies in Income and Wealth, Vol. 37, NBER.

(1974), "International Trade Prices and Price Proxies," in Nancy Ruggles (Ed.), The Role of the Computer in Economic and Social Research in Latin America, NBER.

(1977), "Export Prices and the Transmission of Inflation," American Economic Review, Feb.

(1978), Price Behavior in the tioht of Balance of Pavments Theories. Journal of International Economics, May.

and Dennis M. Bushe (1980), "Prices and Market Shares in the International

. Machinery Trade," NBER Working Paper 521, July.

League of Nations (1945), Industrialization and Foreign Trade, Geneva. 
League of Nations (1945), Industrialization and Foreign Trade, Geneva.

Lipsey, Robert E. (1963), Price and Quantity Trends in the Foreign Trade of the United States, NBER.

Maizels, Alfred (1957), "Unit Value and Volume Indexes of Inter-Area Trade," Journal of the Royal Statistical Society, Series A, General, Vol. 120.

(1963), Industrial Growth and World Trade, National Institute of Economic and Social Research, Economic and Social Studies XXI, Cambridge University Press, Cambridge.

Mill, John Stuart (1848), Principles of Political Economy.

Montgomery, Sarah S. (1960), "The Terms of Trade of Primary Products and Manufactured Goods in International Trade, 1870-1952," Unpublished dissertation, University of Wisconsin.

Morgan, Theodore (1959), "The Long-Run Terms of Trade between Agriculture and Manufacturing," Fconomic Development and Cultural Change, Oct.

(1963), "Trends in Terms of Trade and Their Repercussions on Primary Producers," in R. Harrod (Ed.), International Trade Theory in a Developing Wor I, Macmillan, London.

Murphy, Edward D., (1971), "A Comparison of the Bureau of Labor Statistics" Indexes of Export Prices for Selected U.S. Products with Unit Value and Wholesale Price Indexes," Proceedings of the Business and Economic Statistics Section, American Statistical Association.

Prebisch, Raul (1950), The Economic Development of Latin America and its Principal Problems, United Nations, Economic Commission for Latin America.

Robertson, D.K. (1915), A Study of Industrial Fluctuations, King, London.

Rostin, W. (1974), "Die Indices der Aussenhandelspreise auf Basis 1970," Wirtschaft und Statistik, 6, pp. 387-394.

Rostow, Walt $\mathrm{W}$. (1978), The World Economy, History and Prospect, University of Texas Press.

Singer, Hans (1950), "The Distribution of Gains between Investing and Borrowing Countries," American Economic Review, Vol. 40, May.

Spraos, John (1980), "The Statistical Debate on the Net Barter Terms of Trade between Primary Commodities and Manufactures," Economic Journal,
March.

Summers, Robert (1973), "International Price Comparisons Based upon Incomplete Data," Review of Income and Wealth, Series 19, Number 1, March.

Viner, Jacob (1953), International Trade and Economic Development, Oxford University Press.

Yates, P. Lamartine (1959), Forty Years of Foreign Trade, George Allen \& Unwin, London. 